\title{
Retroperitoneal Ancient Schwannoma
}

\author{
Retroperitoneal Yerleşimli Antik Schwannoma

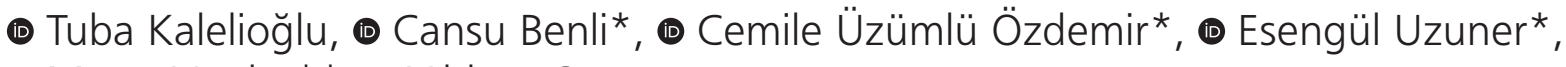 \\ ๑ Murat Vardar**, ๑ Yıldıray Savaş \\ istanbul Haseki Training and Research Hospital, Clinic of Radiology, İstanbul, Turkey \\ *istanbul Haseki Training and Research Hospital, Clinic of Pathology, Istanbul, Turkey \\ **istanbul Haseki Training and Research Hospital, Clinic of General Surgery, Istanbul, Turkey
}

\section{Abstract}

Schwannomas are benign peripheral nerve sheath tumors made up of Schwann cells. Ancient schwannoma is an uncommon subtype of schwannomas exhibiting areas of cystic cavitation, calcification and hyalinization. The "ancient" term refers to tumors that are long standing and show degenerative changes and diffuse hypocellular areas. This case highlights that the possibility of ancient schwannoma should be considered in patients presenting with a retroperitoneal cystic mass.

Keywords: Schwannoma, ancient, retroperitoneal

\section{Introduction}

Schwannoma is most commonly seen tumor among soft-tissue tumors which is composed of Schwann cells of the peripheral nerve sheath. Clinical symptoms are usually pain and paresthesia (1). Schwannomas primarily involve the head, neck and the flexor surfaces of the extremities. Retroperitoneal schwannomas account for only 1-3\% of all schwannomas (2). Ancient schwannoma is also known as degenerative neurilemmoma. It is a subtype of schwannomas and exhibits degeneration and widely hypocellular areas. It is estimated that these appearances occur in long standing schwannomas (1). In this report, we present the principal radiologic features of ancient schwannoma in a patient and review of the current literature.
Öz

Schwannomalar, Schwann hücrelerinden oluşmuş periferik sinir kllıfı tümörleridir. Antik Schwannomalar, Schwannomaların nadir görülen bir alt türü olup kistik kavitasyon alanları, kalsifikasyon ve hyalinizasyon içerirler. "Antik" tabiri uzun süre içerisinde dejeneratif değişiklikler ve diffüz hiposelüler alanlar içermesi nedeniyle kullanılır. Bu olgu sunumu, retroperitoneal bölgede yerleşmiş kistik bir kitlenin antik Schwannoma olabileceğini göz ardı etmememiz gerektiğini göstermektedir.

Anahtar Sözcükler: Schwannoma, antik, retroperitoneal

\section{Case}

Written informed consent was obtained from the patient for publication of this case report. A 58-year-old female was referred to our hospital for evaluation of paresthesia in the right thigh and right iliac fossa pain. Pre- and post-contrast magnetic resonance imaging (MRI) of the abdomen showed a round and well-marginated tumor measuring $5 \times 4 \mathrm{~cm}$ in the right iliac fossa. The tumor was located between the right psoas muscle and the right iliac muscle. MRI findings included low signal intensity on T1- and heterogeneous high signal intensity on T2-weighted images representing cystic-degenerative areas (Figure 1). At post-contrast imaging, areas of solid component showed intense enhancement (Figure 2).
Address for Correspondence/Yazışma Adresi: Yıldıray Savaş İstanbul Haseki Training and Research Hospital, Clinic of Radiology, İstanbul, Turkey Phone: +90 21252944 00/1133 E-mail: ysavas15@gmail.com ORCID ID: orcid.org/0000-0002-8736-7184

Received/Geliş Tarihi: 11 November 2016 Accepted/Kabul Tarihi: 08 March 2017
- Copyright 2019 by The Medical Bulletin of University of Health Sciences Haseki Training and Research Hospital

The Medical Bulletin of Haseki published by Galenos Yayınevi.

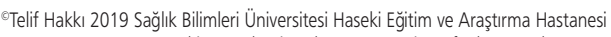
Haseki Tıp Bülteni, Galenos Yayınevi tarafindan yayınlanmıştır. 


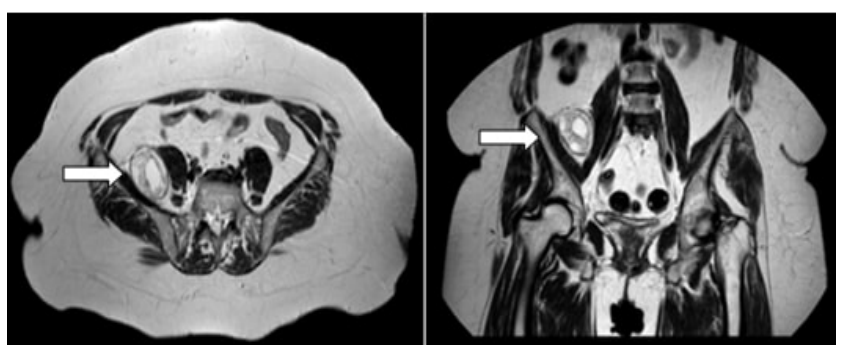

Figure 1. Magnetic resonance imaging T2 weighted image. A multicystic, well marginated tumor (arrow) is located between the right psoas muscle and the right iliacus muscle

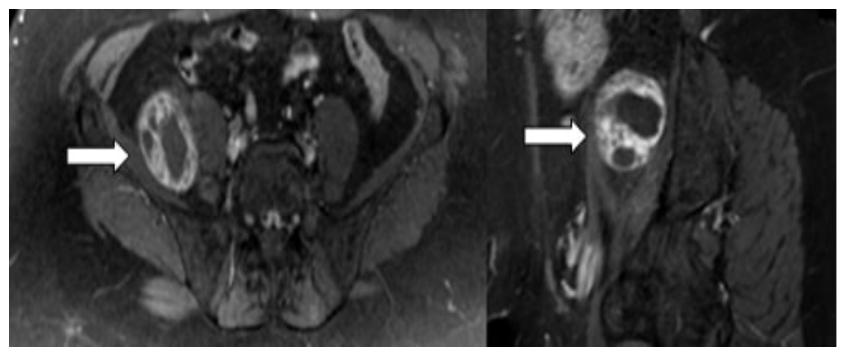

Figure 2. Magnetic resonance imaging post-contrast, at saturated T1 weighted image. Areas of solid components show intense enhancement
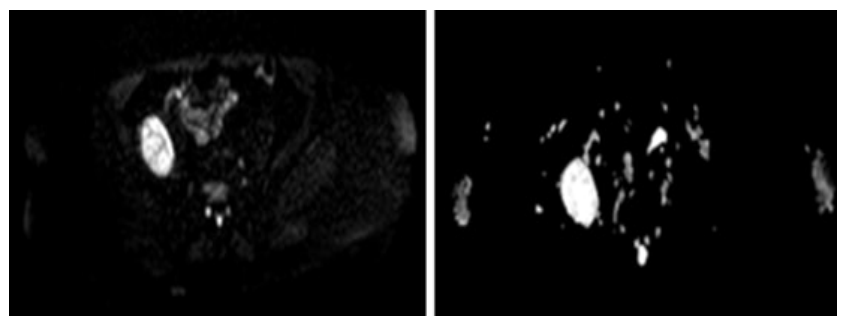

Figure 3. Diffusion-weighted imaging and apparent diffusion coefficient map images. Tumor has no restricted diffusion

On diffusion-weighted imaging and apparent diffusion coefficient map images, the tumor had no restricted diffusion indicating benign behavior (Figure 3). According to these findings, the patient underwent surgery. Intraoperatively, the cystic encapsulated tumor was found between the psoas and the iliac muscle. The tumor was completely excised. Pathologically, the tumor consisted of Schwann cells with areas of high (Antoni A) and low cellularity (Antoni B). Immunohistochemistry study demonstrated that spindle cells were highly positive for S-100 protein and the diagnosis of benign ancient schwannoma was established (Figure 4).

\section{Discussion}

Schwannomas are slow-growing and encapsulated tumors originating from Schwann cells of the peripheral nerve sheath. They are almost always benign. The limbs,
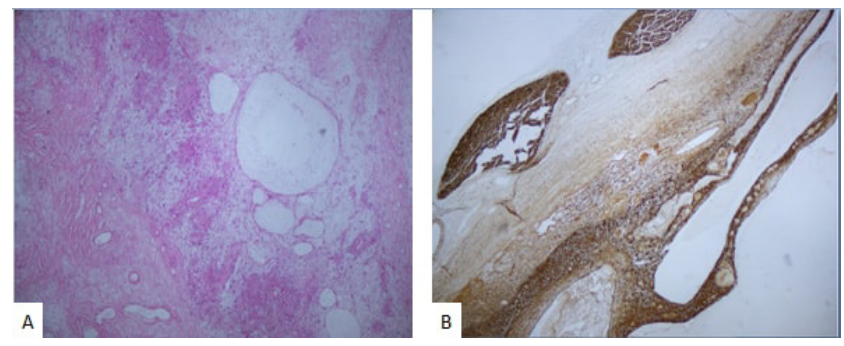

Figure 4. A) Ancient Schwannoma, areas of cyst formations interstitial hyalinization and edema (HE staining, x40). B) Ancient Schwannoma: S100 protein positive immunostaining in tumor cells. Anti-S100 protein immunostaining, x40

head, neck and extremities are common locations for schwannomas $(3,4)$. The paravertebral region, especially near the kidneys, and the presacral region are common locations of retroperitoneal schwannomas. Rarely, they may arise from the abdominal wall, bladder or intestinal wall (5). Pressure effects and pain are most commonly described symptoms of schwannomas (1). Pathologically, they demonstrate a biphasic pattern with regions of high cellular (Antoni type $A$ ) and less cellular areas where a wide myxoid matrix is contained (Antoni type B) (3). Antoni $A$ areas demonstrate dense collection of spindle cells organized in parallel configurations, palisades or whorls. Antoni B areas appear as hypocellularity with mainly loose myxoid matrix (6). Schwannomas are stained positively with S-100, vimentin and neuron-specific enolase and stained negatively with smooth muscle actin and CD117 on immunohistochemical study (7). Retroperitoneal schwannomas are rare tumors commonly seen in middleaged women. The female-to-male ratio is 2:1. (8). The paravertebral region, especially near the kidneys and the presacral region are common locations of retroperitoneal schwannomas. Rarely, they may arise from the abdominal wall, bladder or intestinal wall (5). Ancient schwannoma is a subtype of schwannoma first described by Ackerman and Taylor (9) in 1951. It is characterized by degeneration and decreased cellularity. The term "ancient" refers to tumors growing very slowly. They usually undergo degeneration. Cystic changes represent Antoni type B areas which occupy the majority of the tumor (1). Histologically, they demonstrate characteristic degenerative features of stromal edema, cystic necrosis, perivascular hyalinization, xanthomatous change, fibrosis, calcification, degenerative nuclei with pleomorphism, lobulation, and hyperchromasia $(1,10,11)$. Antoni type A tissue is relatively less seen in these tumors where diffuse hypocellular areas and focal deposition of hyaline material, cystic necrosis, haemorrhagic areas and fatty degeneration are observed (7). Moreover, as the tumor areas usually contain siderophages and histiocytes, and display cellular degenerative changes, and nuclear atypia and pleomorphism are seen with an 
inclination to nuclear palisading, an incorrect diagnosis of malignancy may be made (12). Histologically, positive staining for S-100 protein suggests neural origin especially in the presence of areas of cystic degeneration (13). MRI, shows heterogeneously enhanced masses with cystic areas and may demonstrate calcification or uncommonly, ossification (7). Contrast-enhanced MRI may allow assessment of cystic areas, delineation of the extent of the tumor, and sometimes identifying the continuity of a nerve, thus, characterization of these tumors $(14,15)$. The local extent and internal contexture of the tumor is also better defined by MRI. Myxoid change within the tumor represents the characteristic cystic appearance of low T1 and high T2 signal intensity. After contrast material injection, variable enhancement patterns are seen in the well-defined, complex cystic mass. The fibrous capsule or the residual tumor around the cyst may demonstrate enhancement. Schwannoma can be distinguished from other soft-tissue tumors with their continuity with a nerve (7). Ancient schwannomas may be mistaken for malignant tumors due to nuclear atypia and hyperchromasia (16). However, preservation of spindle shape with large cohesive aggregates of cells in fine needle aspiration cytology and the absence of mitosis demonstrate benign features (11). The head and neck region (16), thorax (17), retroperitoneum, pelvis $(18,19)$ and the extremities $(20)$ are common locations of ancient schwannomas. They are most commonly seen in elderly patients and usually in deep locations (21).

When a mass is found in the paraspinal region, a wide variety of lesions should be differentiated because of their similarities in radiological imaging and clinical characteristics. Psoas abscess requires carrying out thorough physical examinations, close examinations of patient history and comprehensive analysis of imaging reports in immunocompromised patients. Also, neurofibromas usually present with similar clinical, radiological, and histological features. Multinodular and fusiform shaped masses, especially plexiform tumors are seen on MRI. Very similar appearance of non-plexiform types and schwannomas on computed tomography (CT) and MRI makes their differential diagnosis difficult, although the shapes of neurofibromas are more nodular and fusiform (22). The use of fine needle aspiration is supported by many studies in these lesions and, along with $\mathrm{CT}$ and MRI, the accuracy of preoperative diagnosis may be improved (23). The treatment is complete surgical excision for ancient schwannoma. Although these tumors mostly have good prognosis, malignant differentiation has also been reported (24).
Clearly, the paraspinal region may host lesions with a varied behavior ranging from benign to very aggressive tumors. For this reason, the surgeon must be fully aware of the correct diagnosis and pathology to choose the best treatment. Preoperative biopsy is mentioned in many studies and is thought to be very important to guide treatment, to decide the surgical strategy, and to avoid overtreatment and major complications.

\section{Authorship Contributions}

Surgical and Medical Practices: Y.M.V. Consept: T.K. Design: T.K. Data Collection or Processing: C.B., C.Ü.Ö., E.U. Analysis or Interpretation: T.K., Y.S. Literature Search: T.K. Writing: T.K.

Conflict of Interest: No conflict of interest was declared by the authors.

Financial Disclosure: The authors declared that this study received no financial support.

\section{References}

1. Dahl I. Ancient neurilemmoma (schwannoma). Acta Pathol Microbiol Scand A 1977;85:812-8.

2. Dede M, Yagci G, Yenen MC, et al. Retroperitoneal benign schwannoma: report of three cases and analysis of clinicoradiologic findings. Tohoku J Exp Med 2003;200:93-7.

3. Enzinger F, Weiss S. Soft Tissue Tumors, Mosby, St. Louis, Mo. 1995:647-8.

4. Ueda M, Okamoto Y, Ueki M. A pelvic retroperitoneal schwannoma arising in the right paracolpium. Gynecol Oncol 1996;60:480-3.

5. Hoarau N, Slim K, Da Ines D. CT and MR imaging of retroperitoneal schwannoma. Diagn Interv Imaging 2013;94:1133-9.

6. Hide I, Baudouin C, Murray S, Malcolm A. Giant ancient schwannoma of the pelvis. Skeletal Radiol 2000;29:538-42.

7. Isobe K, Shimizu T, Akahane T, Kato H. Imaging of ancient schwannoma. AJR Am J Roentgenol 2004;183:331-6.

8. Singh V, Kapoor R. Atypical presentations of benign retroperitoneal schwannoma: report of three cases with review of literature. Int Urol Nephrol 2005;37:547-9.

9. Ackerman LV, Taylor FH. Neurogenous tumors within the thorax. A clinicopathological evaluation of forty-eight cases. Cancer 1951;4:669-91.

10. Argenyi ZB, Balogh K, Abraham AA. Degenerative ("ancient") changes in benign cutaneous schwannoma. A light microscopic, histochemical and immunohistochemical study. J Cutan Pathol 1993;20:148-53.

11. Dodd LG, Marom EM, Dash RC, Matthews MR, McLendon RE. Fine-needle aspiration cytology of "ancient" schwannoma. Diagn Cytopathol 1999;20:307-11.

12. Lee YS, Kim JO, Park SE. Ancient schwannoma of the thigh mimicking a malignant tumour: a report of two cases, with emphasis on MRI findings. Br J Radiol 2010;83:e154-7. 
13. Takeuchi M, Matsuzaki K, Nishitani H, Uehara H. Ancient schwannoma of the female pelvis. Abdom Imaging 2008;33:247-52.

14. Hayasaka K, Tanaka Y, Soeda S, Huppert P, Claussen C. MR findings in primary retroperitoneal schwannoma. Acta Radiologica 1999;40:78-82.

15. Hughes M, Thomas J, Fisher C, Moskovic E. Imaging features of retroperitoneal and pelvic schwannomas. Clin Radiol 2005;60:886-93.

16. Jayaraj SM, Levine T, Frosh AC, Almeyda JS. Ancient schwannoma masquerading as parotid pleomorphic adenoma. J Laryngol Otol 1997;111:1088-90.

17. McCluggage $W$, Bharucha $H$. Primary pulmonary tumours of nerve sheath origin. Histopathology 1995;26:247-54.

18. Loke T, Yuen N, Lo K, Lo J, Chan J. Retroperitoneal ancient schwannoma: Review of clinico-radiological features. Australas Radiol 1998;42:136-8.
19. Ng K, Sherif A, McClinton S, Ewen S. Giant ancient schwannoma of the urinary bladder presenting as a pelvic mass. Br J Urol 1993;72:513-4.

20. Graviet S, Sinclair G, Kajani N. Ancient schwannoma of the foot. J Foot Ankle Surg 1995;34:46-50.

21. Dayan D, Buchner A, Hirschberg A. Ancient neurilemmoma (schwannoma) of the oral cavity. J Craniomaxillofac Surg 1989;17:280-2.

22. Antonopoulos C, Lilimpakis C, Karagianni M, Daskalopoulou D, Kyriakou T, Vagianos C. Ancient schwannoma of lumbar spine and review of the literature on paraspinal tumors, the role of preoperative biopsy: a case report. Cases J 2009;2:9325.

23. Li Q, Gao C, Juzi JT, Hao X. Analysis of 82 cases of retroperitoneal schwannoma. ANZ J Surg 2007;77:237-40.

24. Rasbridge S, Browse N, Tighe J, Fletcher C. Malignant nerve sheath tumour arising in a benign ancient schwannoma. Histopathology 1989;14:525-8. 